С.С. Шкурупій ${ }^{1}$, В.М. Пилипенко ${ }^{2}$, О.О. Клімішен ${ }^{2}$, M.I. Кожушко ${ }^{2}$, I.О. Атаманенко

${ }^{1}$ Метрологічний центр військових еталонів Збройних Сил Украӥни, Харків

${ }^{2}$ Харківський національний університет Повітряних Сил ім. І. Кожедуба, Харків

${ }^{3}$ Начіональна академія Національної гвардї України, Харків

\title{
АНАЛІЗ МЕТОДІВ СИНХРОНІЗАЦІЇ ЕТАЛОННИХ ЧАСТОТНО-ЧАСОВИХ СИГНАЛІВ ВІЙСЬКОВИМ КОРИСТУВАЧАМ
}

В статті розглядаються основи побудови, зберігання, відтворення, синхронізації та передачі розміру одинииі часу та частоти для військових користувачів. Порівнюються методи синхронізації сигналів статичних та динамічних стандартів за основними джерелами похибок, видами синхросигналів, алгоритмами порівняння, апаратурною реалізацією. Високі темпи вдосконалення еталонів часу $і$ частоти, їх відносна нестабільність визначає актуальність підвищення точності опорних генераторів та удосконалення методів синхронізації. Аналізуються параметри нестабільності фази сигналу синхронізації від автономних стандартів частоти та глобальних навігачійних супутникових систем. Обгрунтовується вибір методу двосторонньої передачі сигналів часу та частоти як найбільш прецизійного.

Ключові слова: супутник, мережа, служба єдиного часу і еталонних частот, точність розподілу часу.

\section{Вступ}

Постановка задачі. Досягнення необхідної точності розподілу частотно-часових сигналів та їх синхронізація для військових систем (наприклад, для тактичних засобів зв'язку, навігаційних систем, систем контролю, ідентифікації та виявлення цілей), задля забезпечення обробки даних та прийомапередачі інформації в нормальних та бойових умовах відіграє важливе значення.

Існує декілька методів передачі точного часу з еталонних джерел опорних стандартів до подальших серверів. Залежно від вимог вибираються та впроваджуються конкретні методи передачі часу [1-3]. Для вимог низької точності реалізовується передача часу через мережу Інтернет (IP-мережі) - це протокол мережевого часу (NTP), протокол (SNTP), протокол (РТР).

Розподіл частотно-часових сигналів за допомогою супутникових систем застосовують як у військових, так і в комерційних цілях. Монопольне положення, яке займають закордонні супутникові радіонавігаційні системи на ринку телекомунікаційного обладнання, відіграє негативну роль в оборонному сегменті країни та може привести до блокування пристрою або переведення в режим розподілу помилкової інформації.

Мета статті. Полягає в теоретичному аналізі методів синхронізації еталонних частотно-часових сигналів для вибору найбільш точного та стабільного за своїми параметрами.

\section{Виклад основного матеріалу}

На сьогоднішній день розробники бортових (наземних) систем управління військовою технікою, апаратними комплексами віддають перевагу глоба- льним навігаційним супутниковим системам ГЛОHACC [4], GALILEO, GPS, BEIDOU на основі технології точного позиціонування, котра не потребує наявності спеціальної інфраструктури для забезпечення коректуючої інформації, та в той же час забезпечує точність позиціонування рухомих засобів на рівні десятків сантиметрів (в режимі фазової неоднозначності). Ця технологія базується на використанні точної інформації частотно-часового та ефемеридного забезпечення ГНСС, а також обробці цих сигналів по коду та фазі. Позиція прямого супутникового сигналу та відбитого сигналу від оточуючої інфраструктури вносить похибки в кодові та фазові вимірювання ГНСС, при цьому для фазових вимірювань характерні втрати цілого числа циклів, які алгоритмічними засобами не завжди можуть коректно компенсуватися.

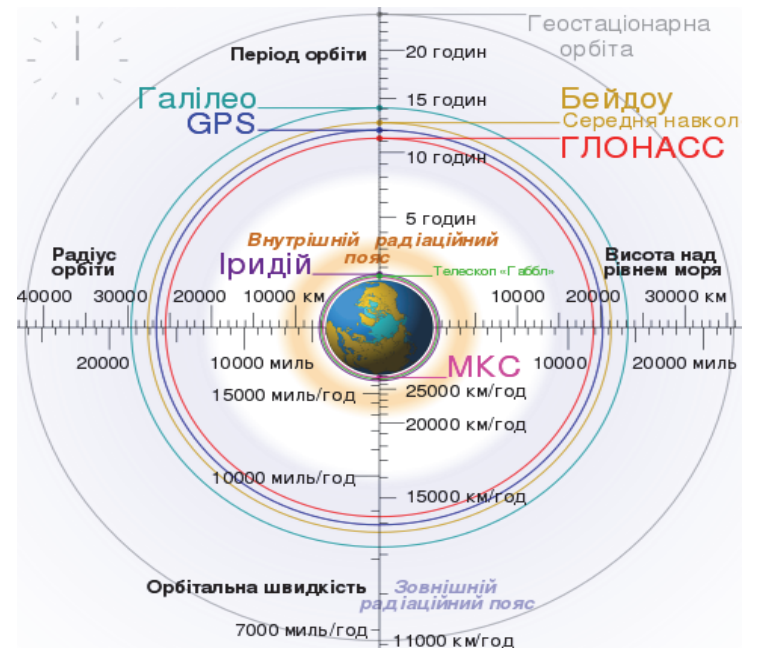

Рис. 1. Система координат глобальних навігаційних супутникових систем Джерело: [5]. 
Дві супутникові системи з чотирьох існуючих використовуються в повному обсязі: російська система ГЛОНАСС [4] та американська система GPS [5]. Обидві системи створювалися для вирішення військових завдань.

Точний час - еталонний сигнал часу та частоти [6]. Еталонне джерело часу, також відоме як стандарт часу, і є високоточним і стабільним стандартом часу, що має найвищі метрологічні якості і значення якого приймається без посилання на інші стандарти. Таким еталонним джерелом часу і частоти є всесвітній координований час (UTC), отриманий та підтримуваний угрупуванням атомних годинників.

Точний час можна передавати за допомогою прямого кабельного з'єднання, через Інтернетмережі, за допомогою навігаційних та комунікаційних систем. Незалежно від того, які методи використовуються, кінцевою метою точної передачі часу $є$ мінімізація похибки стандарту.

Синхронізація сигналу стандарту в межах заздалегідь визначеного рівня точності часового відліку є життєво важливою для синхронних систем:

1. Системи зв'язку: синхронізація часу полягає в тому, щоб сервера в мережах зв'язку забезпечували приймання часового сигналу та його передачу, спільно використовували час, не перекривались і не займали слоти передачі один одного. Синхронізація часу полягає у забезпеченні точної передачіприйома сигналу та обробки даних для отримання інформації у повному обсязі.

2. Системи електронного документообігу (СЕДО): синхронізація параметрів якості телекомунікаційних послуг зв'язку під час статистичної обробки значного обсягу даних з використанням аналізаторів сигналізації.

3. Системи ідентифікації озброєння та цілей: забезпечувати точну ідентифікацію цілі та точність нанесення удару з запобіганням невизначеності відстеження [7].

4. Навігаційні системи: гарантувати точні навігаційні рішення, що надаються від командних центрів підготовки та видачі інформації.

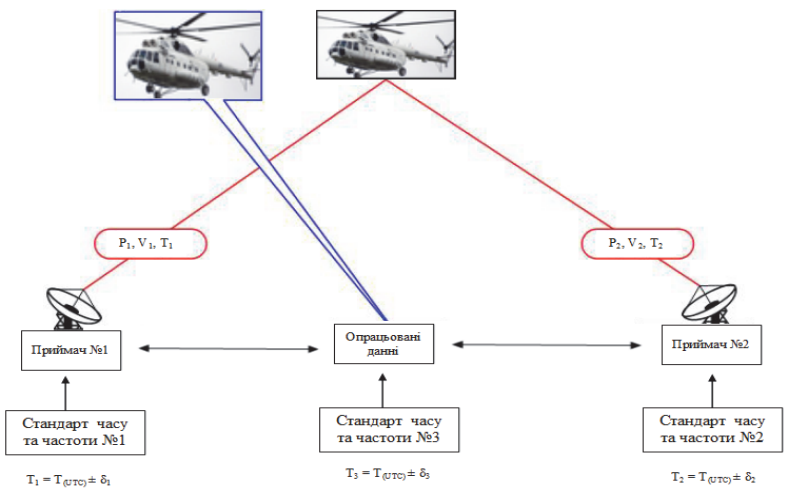

Рис. 2. Вплив асинхронних мережевих годинників Джерело: розроблено авторами.
Як показано на рис. 2, якщо всі годинники в системах ідентифікації та відстеження цілей не синхронізуються, результат ідентифікації цілі виявиться неоднозначним. Ідентифікація цілі являється успішною лише за умови правильного вирівнювання між місцевими та віддаленими позиційними даними як в часі, так і в просторі [8]. Найважливішими показниками ефективності вимірювання одиниць часу та частоти є часова та частотна затримка. Наприклад, стандарт складається 3 генератора, що працює на певній частоті, і механізму підрахунку, який виробляє час від заданого значення (рис. 3).

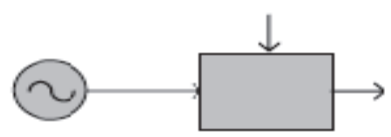

Рис. 3. Генератор та механізм підрахунку Джерело: [8].

Виразимо часову затримку у вигляді формули [1]:

$$
T(t)=T\left(t_{0}\right)+R\left(t-t_{0}\right)+D\left(t-t_{0}\right)^{2}+x(t),
$$

де $t$ - дійсний час;

$t_{0}$ - час $з$ останнього оновлення;

$T$ - часова затримка;

$R$ - частотна затримка;

$D$ - дрейф частоти через старіння компонентів; $x$ - імовірна похибка.

Синхронізація часу - це процес встановлення двох або більше стандартів у мережі на той самий еталонний час. Кінцевою метою будь-якої схеми синхронізації часу є мінімізація зсуву між місцевим часом та еталонним часом для досягнення найвищої точності. Точність часу стандарту залежить від точності та стабільності джерела його частоти, а також від періодичності регулювання відносно вихідного джерела часу.

Точність або зміщення часу визначається як різниця між виміряним імпульсом часу та діючим імпульсом часу, який точно збігається 3 стандартом часу (наприклад, UTC).



Рис. 4. Графік затримки часу Джерело: [6]. 


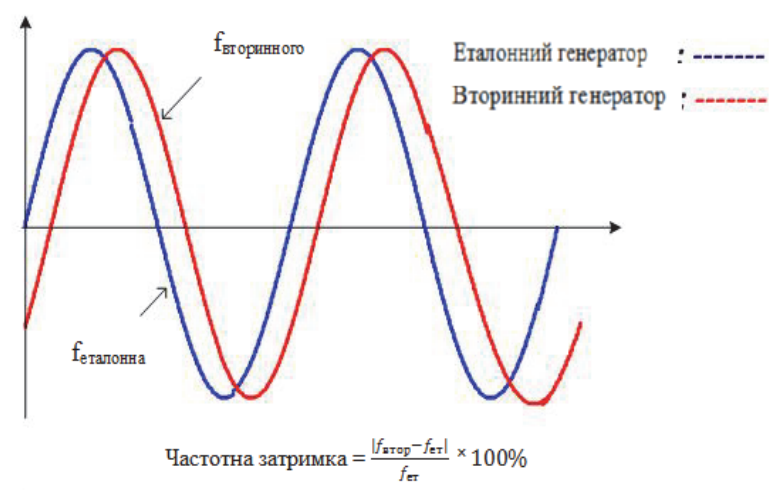

Рис. 5. Графік частотної затримки Джерело: [6].

Налаштування частоти - це процес встановлення двох або більше генераторів коливань в мережі для роботи з однаковою частотою. Зміщення частоти (див. рис. 5) визначається як різниця між вимірюваною частотою та ідеальним стандартом частоти 3 нульовою невизначеністю і $є$ матрицею ефективності частотних налаштувань. Наприклад, генератор на базі цезію (часто його називають годинником цезію) - це генератор 1 ешелону, який має зміщення частоти $1^{\mathrm{e}-13}$ або вище за $1 \mathrm{c}$.

Саме точність часу та мережева синхронізація, а не мультиплексування широкосмугового каналу зв'язку, у вищезазначених системах дозволять визначати якість обслуговування кінцевих користувачів. Для досягнення та підтримки синхронізації часу існує декілька методів передачі точного часу від еталонних джерел до мережевих стандартів [8]. Залежно від вимог точності вибираються та впроваджуються конкретні методи передачі часу.

1. Первинний метод розповсюдження:

- глобальна система позиціонування (GPS).

2. Альтернативні методи:

- автономний стандарт, вбудований в GPSприймач;

- мережевий протокол часу (NTP), простий протокол мережевого часу (SNTP), точний протокол часу (РТР);

- калібровані точні атомні та кварцові годинники;

- двостороння супутникова передача часу і частоти;

- системи зв'язку;

- еталонні станції часу та частоти.

Супутники GPS поширюють час GPS, який відноситься та простежується до Універсального координованого часу UTC [9]. Як результат, одностороння і поширена концепція передачі часу GPS являються двома найпопулярнішими методами передачі часу з доступністю у поєднанні з високою точністю. Односторонній метод широко використовується як військовими, так і цивільними система- ми, тоді як поширені методи найбільш широко використовуються між стандартизованими лабораторіями та установами.

UTC - це часова шкала, що складається 3 входів із часової шкали, отриманої з атомних годинників, і часової шкали, що посилається на обертання Землі. Військово-морська обсерваторія США (USNO) підтримує роботу атомних годинників разом $з$ астрономічними даними для виведення власної версії UTC, позначеної як UTC (USNO). В той же час функціонує Національна шкала координованого часу України UTC (UA) - впорядкована числова послідовність величин одиниць часу, що відтворюється і зберігається Службою єдиного часу і еталонних частот на основі державного еталона одиниць часу і частоти та синхронізована із шкалою Всесвітнього координованого часу UTC.

В методі односторонньої передачі інформації кожен супутник GPS містить безліч високоточних та стабільних атомних стандартів (на основі цезію, рубідію) для розповсюдження часу GPS, що відповідає UTC [10-11]. USNO відстежує час GPS, щоб забезпечити надійний та стабільний узгоджений еталон часу для супутникової навігаційної системи та кінцевих користувачів (рис. 6). Параметри корекції часу GPS являються похідними та надсилаються на Головну станцію управління та контролю GPS (MSC), а потім підключаються до супутників GPS через об'єднані наземні станції зв'язку та моніторингу, з метою корегування навігаційних повідомлень, які передаються на приймачі GPS.

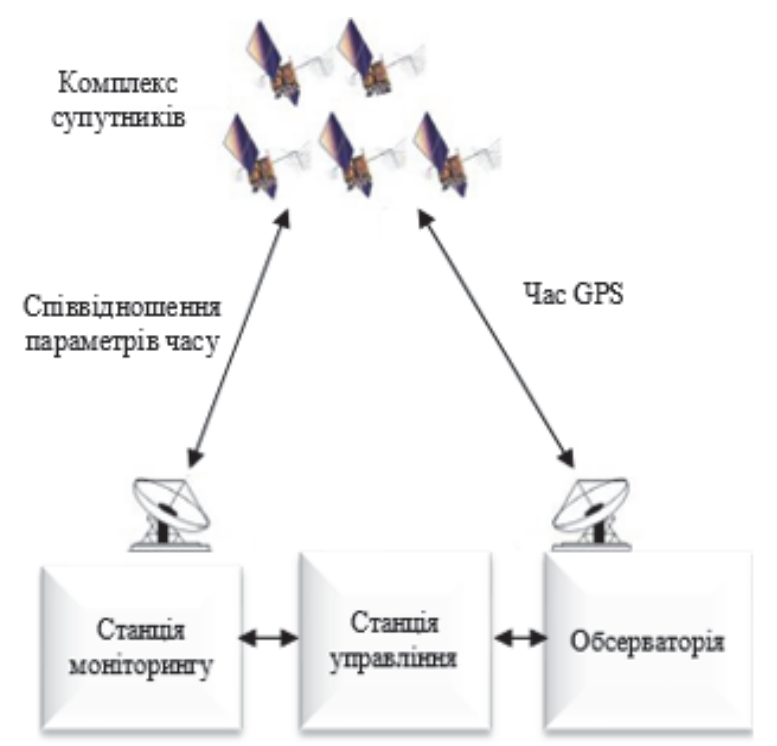

Рис. 6. GPS відстежування та корекція часу Джерело: [10].

Приймач GPS декодує інформацію про хронометраж та параметри корекції часу з отриманих навігаційних повідомлень і використовує корекцію 
свого локально сформованого імпульсу 1PPS для вирівнювання сигналу якомога ближче до UTC.

Приймач GPS може надавати кілька дискретних імпульсів та часові коди. 3 дискретних часових імпульсів стандарт частоти 1 ешелону точності $\left(\geq 1 \mathrm{e}^{-13}\right)$ також може бути створений і наданий за необхідності кінцевим споживачам (рис. 7).

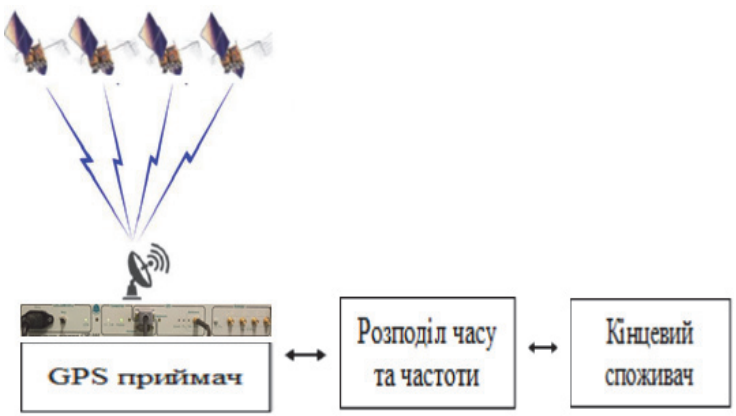

Рис. 7. GPS відстежування та корекція часу Джерело: розроблено авторами за даними [11].

Загальнопоширений метод передачі інформації зображений на рис. 8, обидва стандарти одночасно фіксуються на загальному супутнику GPS і отримують власний час GPS, а потім обчислюють різницю в часі між кожним часовим приймачем та часом GPS.

Різниця в часі змінюється між 2 хронометрами, обчислюється поміж них, та після отримання вихідних даних кожен стандарт має змогу корегувати дії 3 метою налаштування синхронізації.

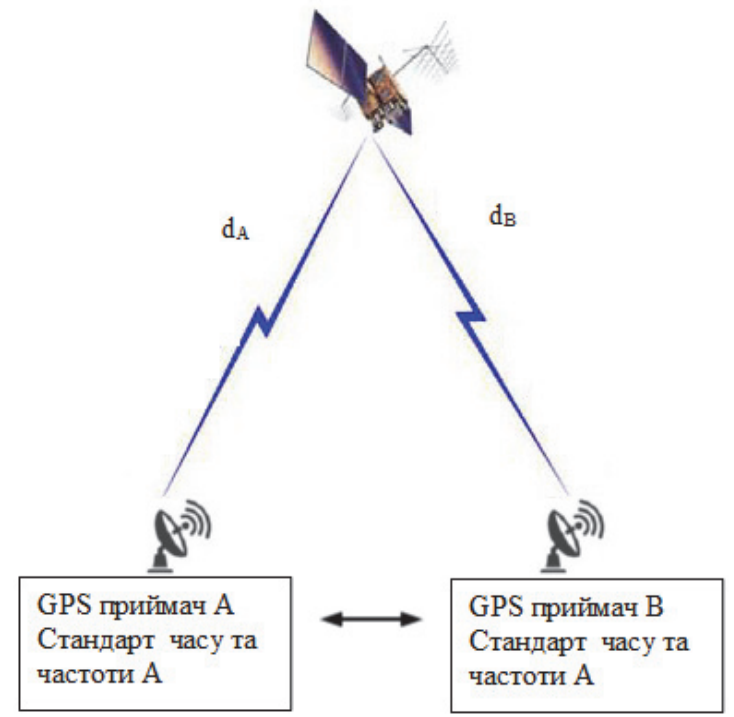

Рис. 8. Принцип передачі точного часу Джерело: розроблено авторами за даними [11].

Цей принцип можемо зобразити формулами:

$$
\begin{aligned}
& \Delta T_{A}=T_{A}-\left(T_{G P S}+d_{A}\right), \\
& \Delta T_{B}=T_{B}-\left(T_{G P S}+d_{B}\right),
\end{aligned}
$$

де $\Delta T_{A}, \Delta T_{B}$ - різниця між стандартом A/B та GPS;
$T_{A}, T_{B}$ - час стандартів A/B;

$T_{G P S}$ - час з супутника;

$d_{A}, d_{B}-$ поширення затримки (нс).

$$
\begin{gathered}
\Delta T_{A}-\Delta T_{B}=\left[T_{A}-\left(T_{G P S}+d_{A}\right)\right]- \\
-\left[T_{B}-\left(T_{G P S}+d_{B}\right)\right]=T_{A}-T_{B}-\left(d_{A}-d_{B}\right),
\end{gathered}
$$

де $\left(d_{A}-d_{B}\right)-0-$ різниця в часових сигналах;

$$
T_{A}-T_{B}=\Delta T_{A}-\Delta T_{B} .
$$

Приймачі GPS надзвичайно вразливі до навмисних радіочастотних перешкод, скажімо, від радіотелевізійних передавачів та випромінювачів GPS завад [12]. Робота GPS порушується, внаслідок чого інші системи, яким потрібен GPS-час, працюють некоректно (рис. 9).

Оскільки GPS все частіше застосовується як основний метод розповсюдження часу та частоти для військових та комерційних систем, покладатись лише на GPS як єдиний засіб точного передавання часу та частоти не гарантує безперервності обслуговування або якісного захисту інформації [13]. Порушення роботи GPS та інтервальні роботи через перешкоди можуть вплинути на функціонування систем навігації, зв'язку, відстеження цілей.

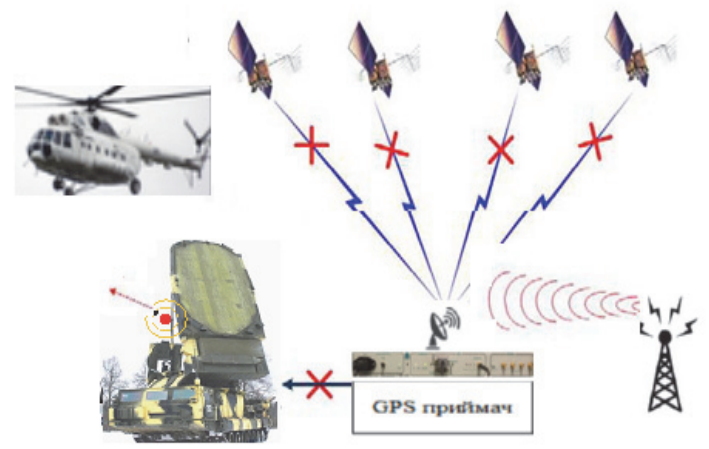

Рис. 9. Створення штучних перешкод для передачі точного часу по GPS

Джерело: розроблено авторами.

Час та частота по GPS можуть безпосередньо доставлятися кінцевим споживачам за допомогою прямих кабельних з'єднань. Однак виникає декілька проблем [14]:

- Кількість користувачів обмежена через кількість вихідних портів $з$ джерела.

- Необхідність невеликого віддалення між джерелом та користувачами, через погіршення сигналу внаслідок передачі.

- Безперервний термін обслуговування не гарантується через пробій кабелю, втрату сигналу, стан мережі.

- Метод прямого розподілу не забезпечує найкращі показники з точки зору точності через можливу відмову єдиного джерела часу. 
Рис. 10 ілюструє архітектуру апаратного комплексу розподілу точного часу GPS, що гарантує безперервність обслуговування (усунення відмови серверу по показникам аварійної сигналізації) на найвищому рівні точності та надійності.

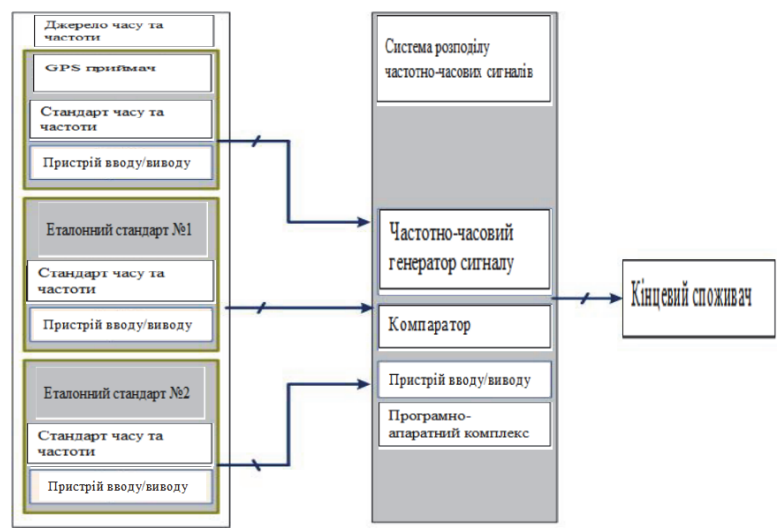

Рис. 10. Підсистема розподілу сигналу точного часу по GPS

Джерело: розроблено авторами за даними [15].

Архітектура реалізована двома основними компонентами: джерелом часу та частоти та системою розподілу.

Оскільки GPS вразливий до радіочастотних перешкод, джерело також складається з еталонних стандартів часу, що не належать до GPS (наприклад, стандарти цезію, рубідію), з метою запобігання відмови серверу та перебоїв в роботі. Багатоканальні джерела дозволяють контролювати цілісність та ефективність роботи на основі принципу трьох генераторів.

Джерела часу від GPS та інші відстежують якість часу один одного і забезпечують самокорекцію джерела 3 найбільшим відхиленням без втручання людини i, таким чином, мінімізують зриви у роботі.

Система розподілу приймає опорні сигнали від джерела, а потім через процес моніторингу відображається найкращий з точки зору точності та стабільності сигнал, котрий в подальшому створюється для формування різних сигналів часу та частоти кінцевим користувачам. Сформовані сигнали не обмежуються 1 Гц, 10 МГц, 1PPS, часовим кодом, T1/E1, T3, а також іншими сигналами.

Конфігурація генераторів (наприклад, генератор коливань на основі рубідію), система розподілу частотно-часових сигналів володіють здатністю утримувати видачу сигналів на тому ж рівні, у випадку коли джерело повністю відмовило у функціонуванні.

Двостороння супутникова передача часу та частоти [16] передбачає найвищий рівень точності до вимог розподілу часу. Обидва сервери одночасно передають один одному сигнал часового коду (на- приклад, імпульс 1PPS зображений на рис. 11). Кожен сервер вимірює інтервал часу між передачею свого локального імпульсу 1PPS і прийомом віддаленого імпульсу 1PPS:

$$
\begin{aligned}
& T I C_{A}=T_{A}-\left(T_{A}+d_{3}+d_{4}+S_{B}\right), \\
& T I C_{B}=T_{B}-\left(T_{A}+d_{1}+d_{2}+S_{A}\right),
\end{aligned}
$$

де $T I C_{A}, T I C_{B}-\triangle 1 \mathrm{PPS}$

$T_{A}, T_{B}$ - час стандартів по 1PPS;

$S_{A}, S_{B}$ - корекція за ефектом Саньяка;

$d_{i}-$ поширення затримки, $i=1,2,3,4$.

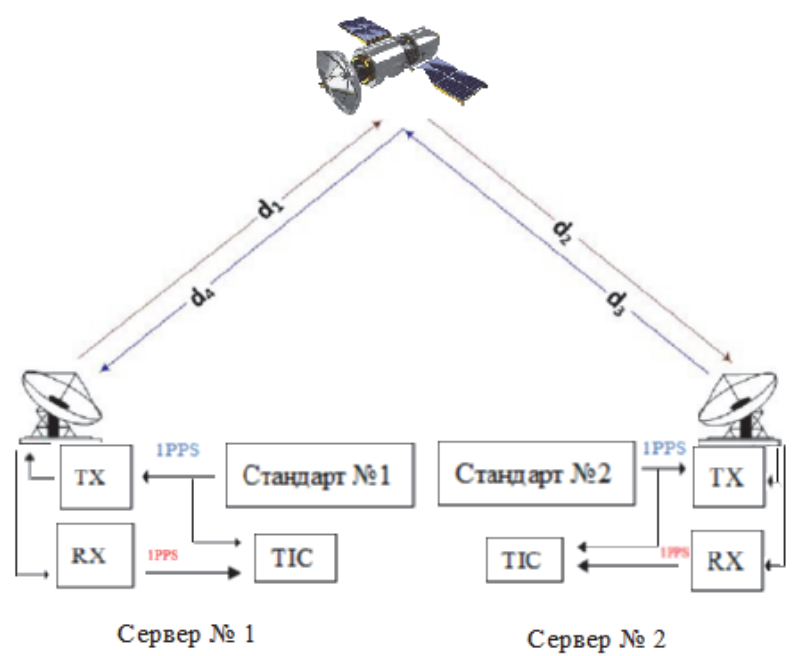

Рис. 11. Двостороння передача сигналу часу та частоти на статичні сервери Джерело: розроблено авторами.

Дані вимірювань обмінюються між серверами для обчислення зсуву між двома тактовими частотами, після чого кожен сервер регулює свій стандарт для досягнення синхронізації часу [17]:

$$
\begin{aligned}
& T_{B}-T_{A}= 0.5 \times\left[\left(T I C_{B}-T I C_{A}\right)-\left(d_{1}-d_{4}\right)-\right. \\
&\left.\left.-\left(d_{2}-d_{3}\right)+\Delta S_{B A}\right)\right], \\
& \Delta S_{B A}=S_{B}-S_{A}=\text { const },
\end{aligned}
$$

Рис. 11 ілюструє ситуацію, в якій обидва сервери статичні. У цьому випадку затримки розповсюдження сигналів між серверами скасовуються, і ефект Саньяка $є$ константою, яка може бути обчислена та компенсована при обчисленні зміщення тактової частоти:

$$
\begin{gathered}
\left(d_{1}-d_{4}\right) \sim 0 \text { та }\left(d_{2}-d_{3}\right) \sim 0, \\
\left.T_{B}-T_{A}=0.5 \times\left[\left(T I C_{B}-T I C_{A}\right)+\Delta S_{B A}\right)\right] .
\end{gathered}
$$

Однак, якщо хоча б один з серверів $є$ динамічним - затримки розповсюдження не скасовуються повністю, і ефект Саньяка змінюється в часі, як показано на рис. 12. 




Рис. 12. Двостороння передача сигналу часу та частоти на динамічний сервер

Джерело: розроблено авторами за даними [18].

Розташування серверів в підсистемі частотночасового забезпечення військових користувачів повинно здійснюватися з урахуванням швидкості передачі повідомлень для кожного клієнта. 3 міркувань економії краще встановлювати менше серверів, що працюють через більшу кількість комутаторів і маршрутизаторів. 3 точки зору стійкості системи слід збільшувати кількість серверів і мінімізувати кількість зв'язків між сервером і користувачем. Потужність головного сервера можна визначити, розділивши максимальну швидкість передачі на кількість клієнтів і кількість транзакцій в секунду. Якщо вимоги перевищують потужність сервера, то слід додати модулі або ще один сервер, щоб розподілити навантаження. Якщо локальний тактовий генератор дає збій, клієнт виставляє запит на обслуговування.
На випадок збою кожен клієнт повинен мати доступ до резервного тактового генератора.

\section{Висновки}

Встановлено, що порівняння методів синхронізації можливе тільки при ідентичних методиках розрахунку похибок вимірювань 3 відповідними алгоритмами вилучення інформації.

Серед розглянутих методів розподілу часу найбільш прецизійним відносно інших є метод двосторонньої передачі інформації, адже точність розрахунку затримки сигналу при односторонній передачі часу по GPS порівняно 3 точністю визначення місцезнаходження для розрахунку ефекту Саньяка на декілька порядків більша.

Для підтримання високої точності різниця затримки розповсюдження між двома сигналами та радіальний рух супутника повинні бути мінімальними протягом інтервалу вимірювання.

Наведено обгрунтування, що при виборі статичних серверів з геосинхронним супутником усі затримки розповсюдження скасовуються, тобто це найкращий варіант.

Метод двосторонньої передачі часу має й ряд суттєвих недоліків - низька завадозахищеність, потреба у високій стабільності та зворотності сигналу. Подальше проведення експериментальних досліджень між центром та регіональними пунктами метрологічного контролю для отримання оціночних значень похибки вимірювань, внаслідок помилкового визначення координат серверів за ефектом Саньяка надасть практичну оцінку можливості застосування визначеного методу.

\section{Список літератури}

1. Golestan S., Vidal A., Yepes A. G., Guerrero J. M., Vasquez J. C., Doval-Gandoy J. A True Open-Loop Synchronization Technique. IEEE Transactions on Industrial Informatics. 2016. Vol. 12. No. 3. P. 1093-1103.

2. IEEE 1588-2008. IEEE Standard for a Precision Clock Synchronization Protocol for Networked Measurement and Control Systems. IEEE, 2008.

3. Питання Служби єдиного часу і еталонних частот : Постанова Кабінету Міністрів України від 02.09.2015 p № 604. Офіиійний вісник Украӥни. 2015. № 72. С. 97.

4. Перов А. И., Харисов В. Н. Глонасс. Принципы построения и функционирования. Москва : Радиотехника, $2005.688 \mathrm{c}$.

5. Parkinson B. W., Spilker Jr. J. Global Position System: Theory and Application. Washington : American Institute of Aeronautics and Astronautics, 1996. 793 p.

6. Конин В. В., Харченко В. П. Системы спутниковой радионавигации. Киев : Холтех, 2010. 520 с.

7. Руководство по усовершенствованным системам управления наземным движением и контроля за ним (A-SMGCS). ИКАО. (Doc 9830AN/452). 2004. 100 c.

8. Основы спутниковой навигации U-blox. GPS-X-02007-D. 2009. 174 с.

9. Егоров В. В., Корнеев И. Л. Задачи практического применения локальных систем навигации: Международный форум “Микроэлектроника-2019”: сборник тезисов. 2019. С. 53.

10. Kulakov O., Katunin A., Kozhushko Ya., Herasymov S., Roianov O., Gorbach T. Usage of Lidar Systems for Detection of Hazardous Substances in Various Weather Conditions. IEEE 6th International Symposium on Microwaves, Radar and Remote Sensing (MRRS), 2020. P. 360-363.

11. ДСТУ 4162:2003. Станції супутникової системи зв'язку земні. Класифікація. Основні параметри та методи вимірювання. ETSI EN 301443 V 1.2.1:2001, NEQ. [Чинний від 2044-07-01]. Київ : Держспоживстандарт України, 2004.20 с.

12. Шинкарук О. М., Правда В. І., Бойко Ю. М. Приймання та оброблення сигналів. Хмельницький : ХНУ, 2013. $365 \mathrm{c}$ 
13. Радзиевский В. Г., Агафонов А. А. Современная радиоэлектронная борьба. Вопросы методологии. Москва : Радиотехника, 2006. С. 424.

14. Горностаев Ю. М., Соколов В. В., Невдяев Л. М. Перспективные системы спутниковой связи. Москва : Горячая линия, 2015. $132 \mathrm{c}$.

15. Шевцов М. М., Гаврилов А. Б., Бойко В. М., Шуригін О. В. Сучасні вимоги до програмно-апаратного комплексу з повірки, випробувань і сертифікації апаратури споживачів глобальних навігаційних супутникових систем. Озброєння та військова техніка. 2016. № 3(11). С. 60-65.

16. Довгополий А. С., Понамаренко С. О., Твердохлібов В. В., Білобородов О. О. Удосконалення систем супутникової навігації озброєння та військової техніки в умовах впливу навмисних перешкод. Озброєння та військова техніка. 2018. № 1(17). С. 67-71.

17. Мазуренко Д. К. Измерение качества передачи сигналов точного времени в сети связи с пакетной коммутацией. Телекоммуникации и транспорт. 2016. Том 10. № 7. С. 35-40.

18. Кирилюк В. А. Критерій вибору позиції станції перешкод бортовим радіолокаційним станціям. Труди університету: зб. наук. праџь. 2011. № 1 (103). С. 155-160.

\section{Відомості про авторів:}

\section{Шкурупій Станіслав Сергійович}

молодший науковий співробітник

Метрологічного центру військових еталонів ЗСУ,

Харків, Україна

https://orcid.org/0000-0001-6151-1195

\section{Пилипенко Віталій Миколайович}

заступник начальника відділу

Харківського національного університету

Повітряних Сил ім. І. Кожедуба,

Харків, Україна

https://orcid.org/0000-0002-3912-4372

\section{Клімішен Олексій Олегович}

кандидат технічних наук старший науковий співробітник старший викладач

Харківського національного університету

Повітряних Сил ім. І. Кожедуба,

Харків, Україна

https://orcid.org/0000-0003-3859-1531

\section{Кожушко Микола Іванович}

науковий співробітник

Харківського національного університету

Повітряних Сил ім. І. Кожедуба,

Харків, Україна

https://orcid.org/0000-0001-5410-1657

\author{
Атаманенко Ігор Олександрович \\ старший викладач \\ Національної академії Національної гвардії України, \\ Харків, Україна \\ https://orcid.org/0000-0001-8959-5423
}

\section{Information about the authors:}

\author{
Stanislav Shkurupii \\ Junior Researcher \\ of Metrological Centre of Military Standards, \\ Kharkiv, Ukraine \\ https://orcid.org/0000-0001-6151-1195
}

\section{Vitalii Pilipenko}

Deputy Head of Scientific Research Department

of Ivan Kozhedub Kharkiv National

Air Force University,

Kharkiv, Ukraine

https://orcid.org/0000-0002-3912-4372

\section{Oleksiy Klimishen}

$\mathrm{PhD}$ in Engineering Senior Researcher

Senior Lecturer

of Ivan Kozhedub Kharkiv National

Air Force University,

Kharkiv, Ukraine

https://orcid.org/0000-0003-3859-1531

\author{
Mykola Kozhushko \\ Researcher \\ of Ivan Kozhedub Kharkiv National \\ Air Force University, \\ Kharkiv, Ukraine \\ https://orcid.org/0000-0001-5410-1657
}

\author{
Ihor Atamanenko \\ Senior Lecturer \\ of the National Academy of the National Guard of Ukraine, \\ Kharkiv, Ukraine \\ https://orcid.org/0000-0001-8959-5423
}

\section{АНАЛИЗ МЕТОДОВ СИНХРОНИЗАЦИИ ЭТАЛОННЫХ ЧАСТОТНО-ВРЕМЕННЫХ СИГНАЛОВ ВОЕННЫМ ПОТРЕБИТЕЛЯМ}

С.С. Шкурупий, В.Н. Пылыпенко, А.О. Климишен, Н.И. Кожушко, И.А. Атаманенко

В статье рассматриваются основы построения, хранения, воспроизведения, синхронизачии и передачи размера единицы времени и частоты для военных потребителей. Сравниваются методы синхронизации сигналов статических и динамических стандартов по основным источникам погрешностей, видам синхросигналов, алгоритмам сравнения, аппаратурной реализации. Высокие темпь усовериенствования эталонов времени и частоты, их относительная нестабильность определяют актуальность повышения точности опорных генераторов и усовершенствования методов синхронизации. Анализируются параметры нестабильности фазы сигнала синхронизации от автономных стандартов частоты и глобальной навигационной спутниковой системы. Приводятся доказательства выбора метода двухсторонней передачи времени и частоты как наиболее прецизионного.

Ключевые слова: спутник, сеть, служба единого времени и эталонных частот, точность распределения времени. 


\section{AN ANALYSIS OF METHODS SYNCHRONIZATION OF REFERENCE FREQUENCY AND TIME SIGNALS TO MILITARY CONSUMERS}

S. Shkurupii, V. Pilipenko, O. Klimishen, M. Kozhushko, I. Atamanenko

The article considers the basics of construction, storage, reproduction, synchronization and transmission of a pitch chain signal of time and frequency for military consumers. The methods of signal synchronization of static and dynamic standards by main sources of errors, types of signals, comparison algorithms, hardware implementation are compared. The high rates of improvement of time and frequency standards, their relative instability determine the relevance of increasing the accuracy of reference oscillators and improving synchronization methods. The parameters of phase instability of the signal synchronization from autonomous frequency standards and global navigation satellite systems are analyzed. The proofs of the choice of the method of two-way satellite time and frequency transfer as the most precise are given. It is established that the comparison of synchronization methods is possible only with identical methods of calculation of measurement errors with the corresponding algorithms of information extraction.

Among the considered methods of time distribution the most precise in relation to others is the method of two-way transmission of information, because the accuracy of calculating the signal delay in one-way GPS transmission compared to the accuracy of location to calculate the Sagnac effect is several orders of magnitude higher.

To maintain high accuracy, the difference in propagation delay between the two signals and the radial motion of the satellite must be minimal during the measurement interval. The rationale is given when selecting static servers with a geosynchronous satellite, all propagation delays are eliminated, ie this is the best option.

The method of two-way time transmission has a number of significant disadvantages: low noise immunity, the need for high stability and signal reversibility. Further experimental research between the center and regional metrological control points to obtain estimated values of measurement error, due to erroneous determination of server coordinates by the Sagnac effect will provide a practical assessment of the feasibility of applying a particular method. In the communication of digital information, the rates at which the bits that make up the signals and messages are generated must be in step with one another or the message cannot be read.

For reasons of economy, it is better to install fewer servers running more switches and routers. From the point of view of system stability, it is necessary to increase the number of servers and to minimize the number of connections between the server and the subscriber. The capacity of the master server can be determined by dividing the maximum transfer rate by the number of clients and the number of transactions per second. If the requirements exceed the capacity of the server, you should add modules or another server to distribute the load. If the local clock fails, the customer makes a service request. In case of failure, each client must have access to a backup clock.

Keywords: satellite, network, time and reference frequencies service, accuracy of time distribution. 